\title{
西宁盆地新生代磁性地层研究新进展
}

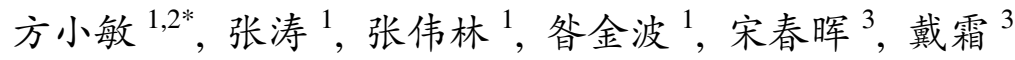 \\ 1. 中国科学院青藏高原研究所, 中国科学院青藏高原地球科学卓越创新中心, 北京 100101 ; \\ 2. 中国科学院大学, 北京 100049 ; \\ 3. 兰州大学地质科学与矿产资源学院, 兰州 730000 \\ * 联系人, E-mail: fangxm@itpcas.ac.cn
}

\section{Advances of Cenozoic magnetostratigraphy of the Xining Basin}

\author{
Xiaomin Fang ${ }^{1,2^{*}}$, Tao Zhang ${ }^{1}$, Weilin Zhang ${ }^{1}$, Jinbo Zan ${ }^{1}$, Chunhui Song ${ }^{3}$ \& Shuang Dai ${ }^{3}$ \\ ${ }^{1}$ Institute of Tibetan Plateau Research, Center for Excellence in Tibetan Plateau Earth Sciences, Chinese Academy of Sciences, Beijing 100101, China; \\ ${ }^{2}$ University of Chinese Academy of Sciences, Beijing 100049, China; \\ ${ }^{3}$ School of Earth Sciences, Lanzhou University, Lanzhou 730000, China \\ * Corresponding author, E-mail: fangxm@itpcas.ac.cn \\ doi: 10.1360/N972019-00130
}

西宁盆地是青藏高原向东北扩展生长的“前哨”,也 是东亚季风湿润气候向中亚内陆干旱气候过渡的核心 地带. 盆地内堆积了厚层、几乎连续的以细粒河湖相为 主的新生代沉积物, 含有丰富的哺乳动物化石, 尤以中 国早中新世标准动物群一一谢家动物群而著名. 顶部河 流阶地上覆盖了厚层风成粉尘堆积, 它们详细记录了 亚洲内陆干旱和东亚季风演化、动植物演替以及黄河形 成与高原隆升过程等重要信息. 因此, 西宁盆地的古生 物气候地层学自 20 世纪 70 年代发现谢家动物群以来, 一直备受关注. 然而, 西宁盆地新生界年代学、特别是 含谢家动物群化石地层的准确时间标尺至今并未能达 成共识且争议颇大, 严重阻碍了对上述热点科学问题 的深人探讨.

为此, 我们对不同研究组所开展的剖面地层序列、 岩相特征和古地磁测年进行了详细的野外核查和分析, 并在盆地中央选择了地层出露较为完整、连续的剖面开 展新的高分辨率古地磁年代学研究, 结合盆地古生物、 地层序列、岩相和磁性地层的综合集成分析, 以及含谢 家动物群剖面底部最新发现的火山灰绝对测年结果 ${ }^{[1]}$, 获得了以下重要认识(图1): (1) 不同研究小组在盆地不 同地点/剖面所获得的古地磁极性事件以及地层岩相序 列都具有很高的相似性和可对比性, 重新厘定和确定 盆地新生代大约从 $54 \mathrm{Ma}$ 开始河湖相沉积并连续堆积至
$4.8 \mathrm{Ma}$, 从而建立了青藏高原东北部最完整、连续的新 生代地层高精度年代序列; (2) 确证谢家动物群的年代 为晚渐新世约 $25 \mathrm{Ma}$, 为修订中国陆相“谢家阶”和相应 的陆生哺乳动物分期“谢家期”提供了年代学依据; (3) 限定盆地纯风成粉尘红黏土的堆积时间以及最高阶地 的形成时间均在约4.8 3.6 Ma以来, 揭示黄河上游最大 支流(湟水流域)自此开始形成; (4) 发现盆地新生代多 种气候代用指标记录与全球温度变化趋势和事件基本 吻合, 暗示全球变冷可能是亚洲内陆干旱化的主控因 子, 高原隆升和副特提斯海退却的影响叠加其上; (5) 发现西宁盆地经历了盆地形成到消亡的完整沉积环境 演化过程, 记录了祁连山东段新生代经历的三大构造 隆升阶段: 早期开始于约 $54 \mathrm{Ma}$ 和中期 $22.5 \mathrm{Ma}$ 的缓慢隆 升, 晚期17 Ma、8 7 Ma以及4.8 3.6 Ma以来开始明显加 速的幕式强烈隆升, 它们是对印度板块与欧亚板块自 约55 Ma开始碰撞以来持续推挤变形的远程同步响应, 暗示需要新的青藏高原的变形隆升机制才能解释. 这 是高原东北部系统建立的新生代最完整、连续的高精度 年代序列, 为生物地层学、古气候学、地貌学及构造地 质学等相关研究奠定了准确的年代学基础, 对深人理 解青藏高原隆升、干旱-季风系统和生物多样性演化与 未来气候变化具有重要的促进作用. 更多内容可参见 Fang等人 ${ }^{[10]}$ 在Earth Science Reviews 上最新发表的论文. 


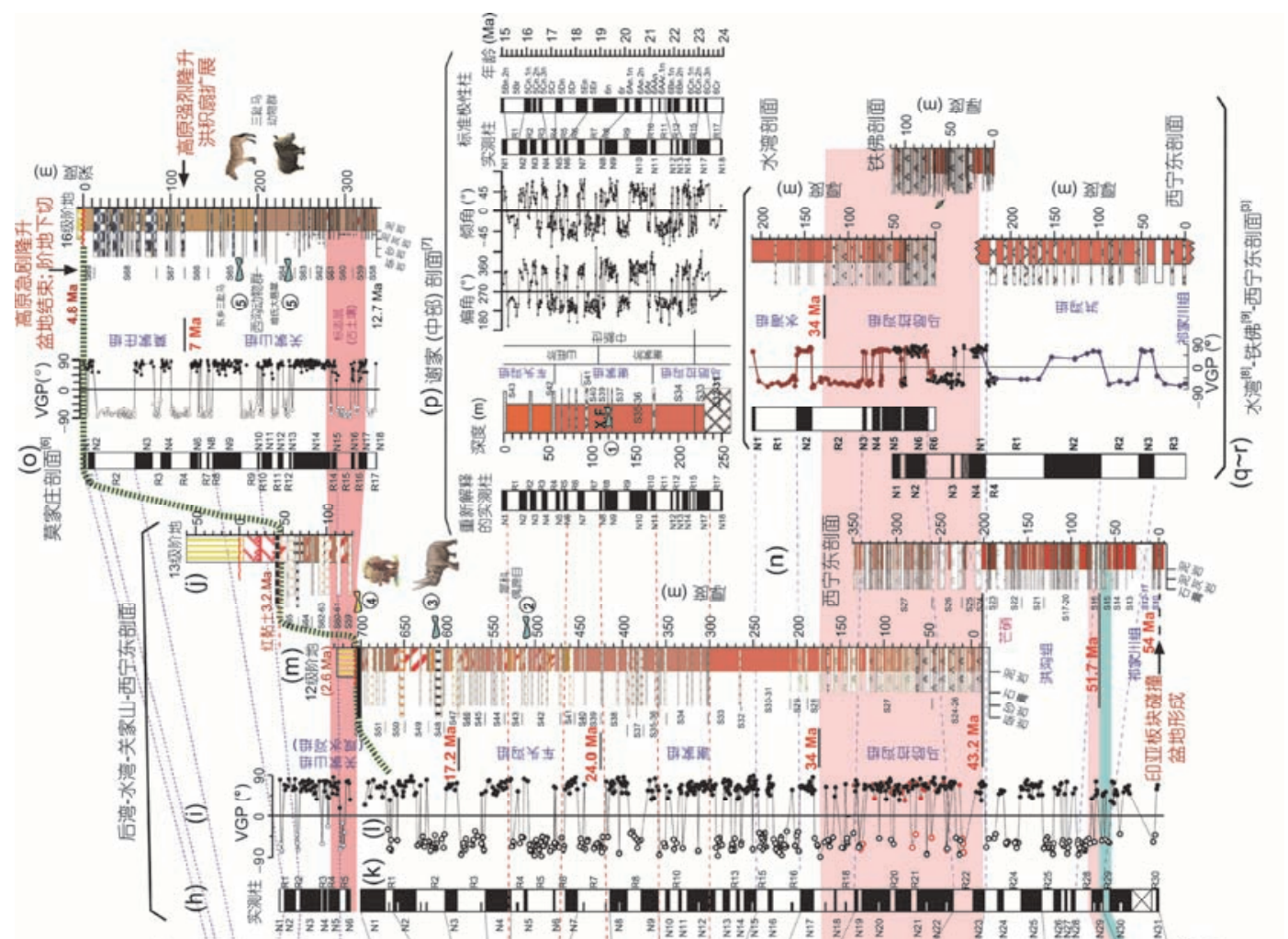

60 蓄

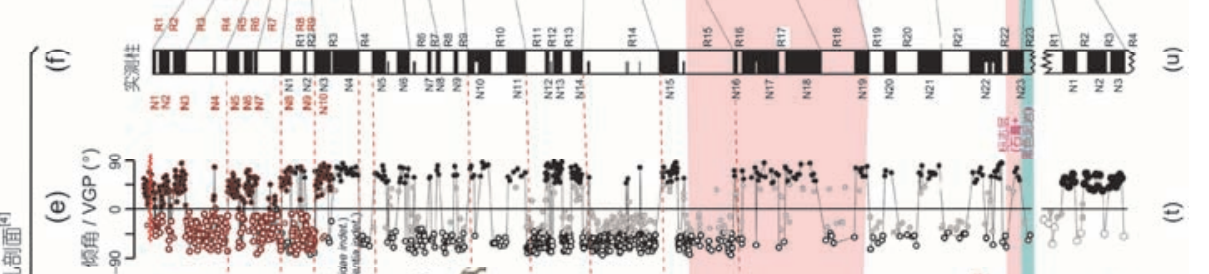

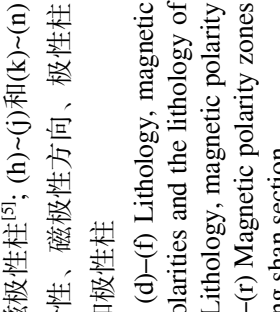

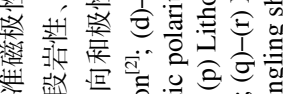

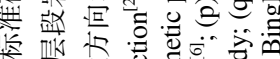

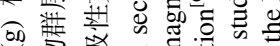

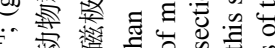

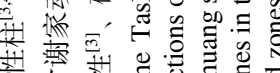

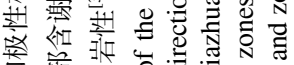

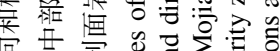

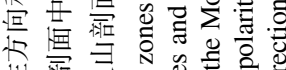

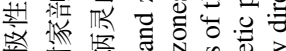

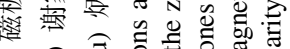

论

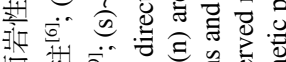

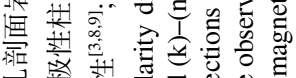

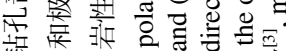

焉要

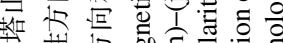

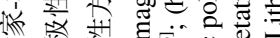

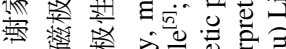

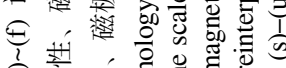

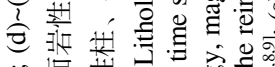

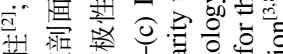

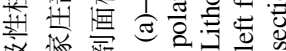

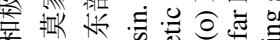

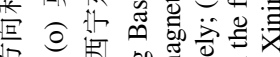

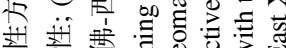

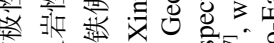

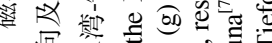

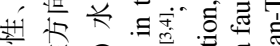

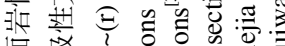

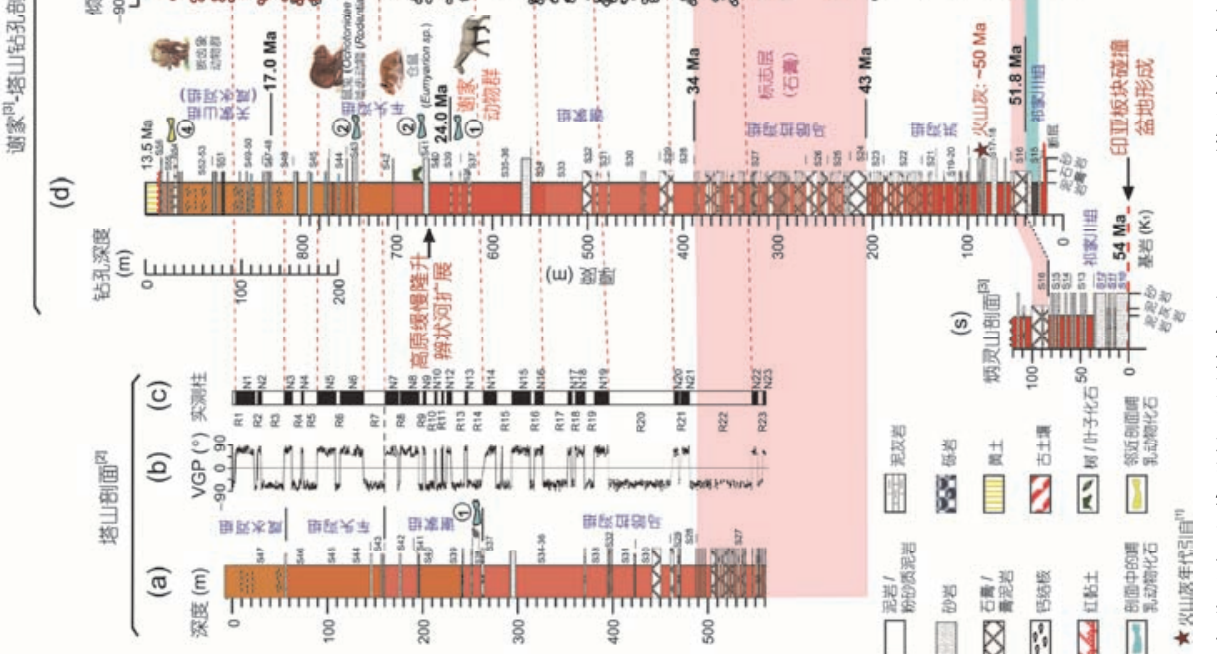

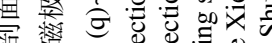

蓶, 泳

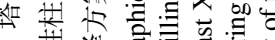

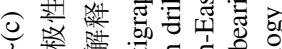

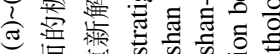

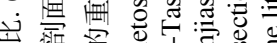

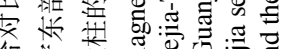

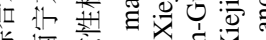

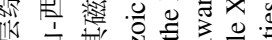

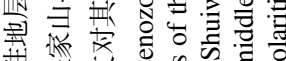

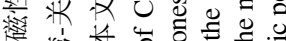

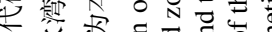

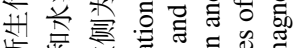

雭

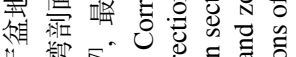

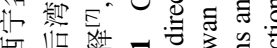

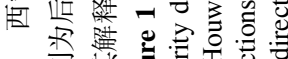

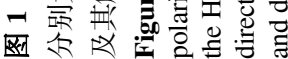




\section{参考文献}

1 Meijer N, Dupont-Nivet G, Abels H A, et al. Central Asian moisture modulated by proto-Paratethys Sea incursions since the early Eocene. Earth Planet Sci Lett, 2019, 510: 73-84

2 Xiao G Q, Guo Z T, Dupont-Nivet G, et al. Evidence for northeastern Tibetan Plateau uplift between 25 and 20 Ma in the sedimentary archive of the Xining Basin, Northwestern China. Earth Planet Sci Lett, 2012, 317-318: 185-195

3 Dai S, Fang X M, Dupont-Nivet G, et al. Magnetostratigraphy of Cenozoic sediments from the Xining Basin: Tectonic implications for the northeastern Tibetan Plateau. J Geophys Res, 2006, 111: 335-360

4 Zan J B, Fang X M, Yan M D, et al. Lithologic and rock magnetic evidence for the Mid-Miocene climatic optimum recorded in the sedimentary archive of the Xining Basin, NE Tibetan Plateau. Palaeogeogr Palaeoclimatol Palaeoecol, 2015, 431: 6-14

5 Gradstein F M, Ogg J G, Schmitz M D, et al. The Geologic Time Scale. Amsterdam: Elsevier, 2012. 923-978

6 Yang R S, Fang X M, Meng Q Q, et al. Paleomagnetic constraints on the middle Mioceneearly Pliocene stratigraphy in the Xining Basin, NE Tibetan Plateau, and the geologic implications. Geochem Geophys Geosyst, 2017, 18: 3741-3757

7 Wu L C, Yue L P, Wang J Q, et al. Magnetostratigraphy stratotype section of the Neogene Xiejian stage. J Stratigr, 2006, 30: 50-53[武力 超, 岳乐平, 王建其, 等. 新近系谢家阶层型剖面古地磁年代学研究. 地层学杂志, 2006, 30: 50-53]

8 Horton B K, Dupont-Nivet G, Zhou J, et al. Mesozoic-Cenozoic evolution of the Xining-Minhe and Dangchang basins, northeastern Tibetan Plateau: Magnetostratigraphic and biostratigraphic results. J Geophys Res, 2004, 109: 657-681

9 Bosboom R E, Abels H A, Hoorn C, et al. Aridification in continental Asia after the Middle Eocene Climatic Optimum (MECO). Earth Planet Sci Lett, 2014, 389: 34-42

10 Fang X M, Fang Y H, Zan J B, et al. Cenozoic magnetostratigraphy of the Xining Basin, NE Tibetan Plateau, and its constraints on paleontological, sedimentological and tectonomorphological evolution. Earth Sci Rev, 2019, 190: 460-485 